\title{
Evidence of Large-Scale Wave Disturbances in the Equatorial Lower Stratosphere*
}

\author{
By T. Maruyama and M. Yanai \\ Geophysical Institute, Tokyo University, Tokyo \\ (Manuscript received 20 December 1966)
}

\section{Introduction}

In a previous paper, the authors (Yanai and Maruyama, 1966) described short-period wind oscillations in the lower stratospheric westerlies over the equatorial Pacific area during early 1958. They noted that 1) the wind direction at around $21 \mathrm{~km}$ height shifts between $240^{\circ}$ and $300^{\circ}$ with an average period of 5 days or so, 2) the phase of wind oscillation shows a downward propagation at a speed of roughly $1 \mathrm{~km} /$ day and 3 ) the phase of wind oscillation propagates westward at a speed of roughly $2000 \mathrm{~km} / \mathrm{day}$. Based on these facts and findings of similar oscillations in other areas of the equatorial belt, they suggested the existence of large- scale wave disturbances in the equatorial lower stratosphere. Since then, further analysis of stratospheric winds has been accumulated so that it is now possible to depict a synoptic picture of the disturbance.

2. General features of stratospheric winds over the equatorial Pacific from April to June 1958

So far, our major data source has been the upper wind data over the Marshall Islands area taken during the 1958 test period (Data A). To describe general features of stratospheric winds during this period, 10-day running averages of zonal wind components have been computed. In Fig. 1, the vertical cross section of mean zonal wind for 15-24 April is illustrated. This section is constructed based on the data of Kapingamarangi $\left(1^{\circ} \mathrm{N}\right)$, Ponape $\left(7^{\circ} \mathrm{N}\right)$, Eniwetok $\left(11^{\circ} \mathrm{N}\right)$ and Wake $\left(19^{\circ} \mathrm{N}\right)$ (See Fig. 5). We notice a core of lower stratospheric westerlies centered around $20 \mathrm{~km}$ height over the equator. Another core of westerlies in the troposphere over Wake is

\footnotetext{
* Division of Meteorology, Contribution No. 154.
}

MEAN ZONAL WIND 15-24 APRIL 1958

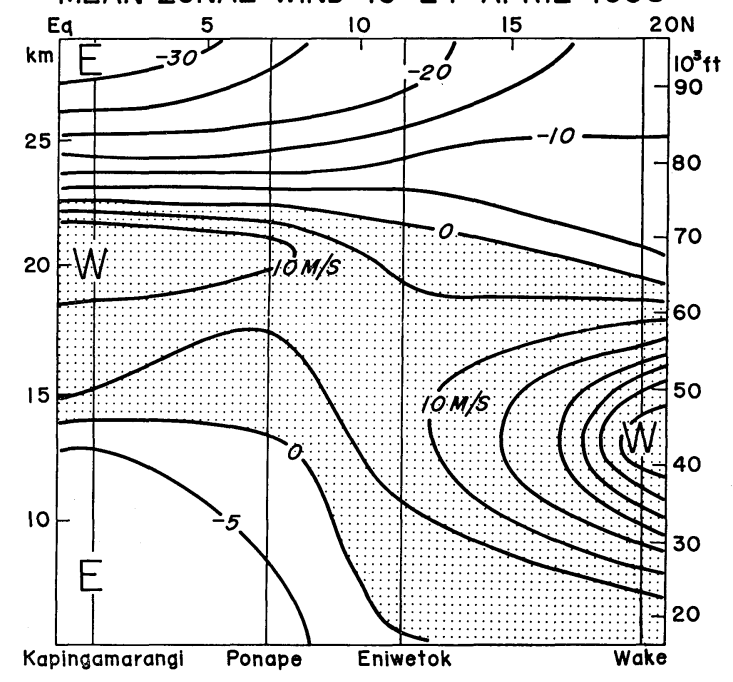

Fig. 1. Mean zonal wind in the lower stratosphere and in the upper troposphere over the equatorial Pacific area for 15-24 April 1958.

believed to be of middle-latitude origin. At higher altitudes, a strong easterly current was blowing.

Fig. 2 shows the vertical time section of 10-day average zonal winds at Canton Island. During April through June 1958, the height of the core of lower stratospheric westerlies was gradually decreasing and the westerlies was being replaced by the high-level easterlies from above. Weakening of the lower stratospheric westerlies is clearly seen in the time change of its horizontal width. As seen in Fig. 3, the northern boundary of the belt of westerlies at $70,000 \mathrm{ft}(21.3 \mathrm{~km})$ height was situated at around $18^{\circ} \mathrm{N}$ in the beginning of April 1958. The boundary was at around $2^{\circ} \mathrm{N}$ at the end of June 1958.

\section{Nature of large-scale wave disturbances}

The structure of large-scale wave distur- 
MEAN ZONAL WIND AT CANTON ISLAND

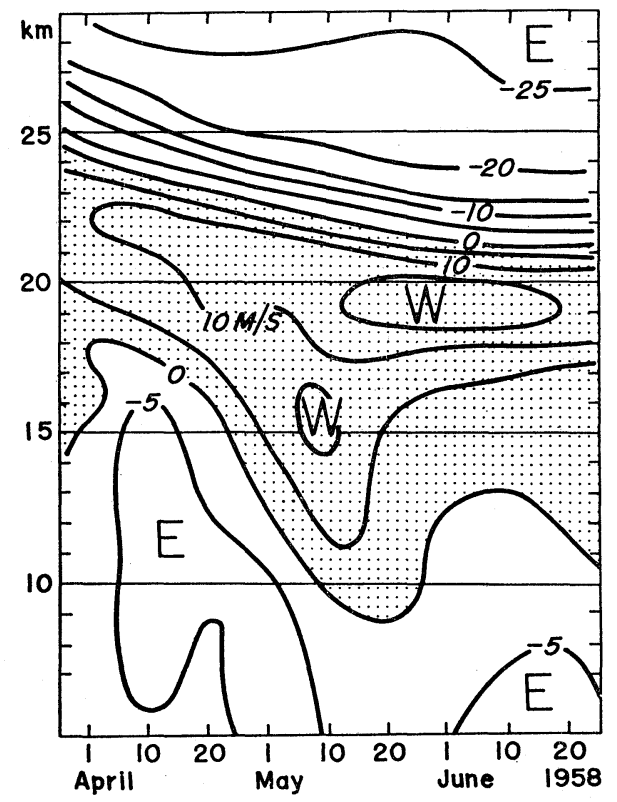

Fig. 2. Time change of 10-day mean zonal wind at Canton Island from April to June 1958.

MEAN ZONAL WIND AT 70,000FT (10

Fig. 3. Time change of 10-day mean zonal wind at $70,000 \mathrm{ft}$ height over the equatorial Pacific area from April to June 1958.

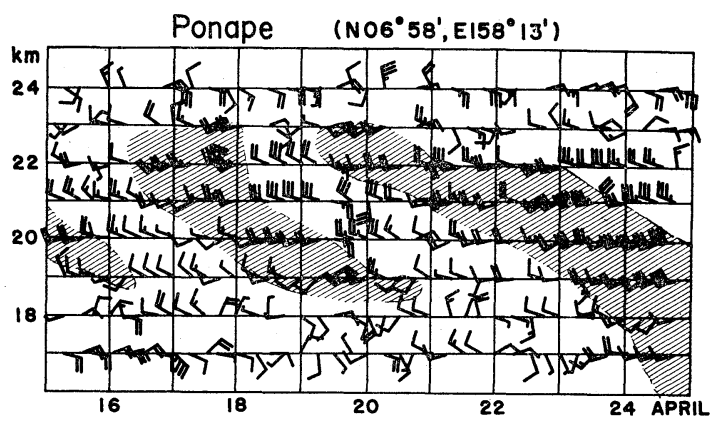

Canton Island $\left(502^{\circ} 46^{\prime}\right.$, W $\left.171^{\circ} 43^{\prime}\right)$

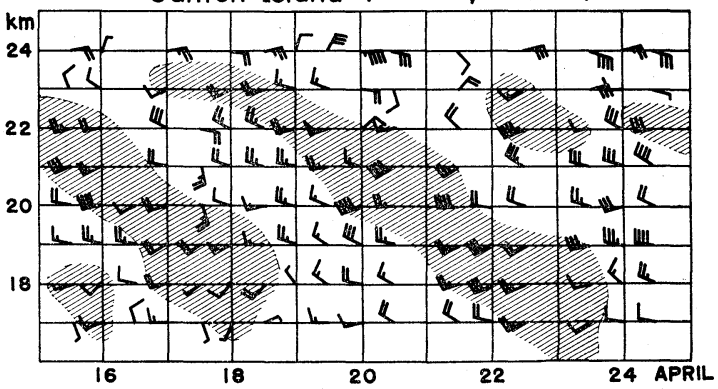

Fig. 4. Vertical time section of lower stratospheric winds from 15 to 24 April 1958, a) Ponape (top), b) Canton Island (bottom).

bances found in the lower stratospheric westerlies may be best demonstrated in two vertical time sections shown in Fig. 4. Fig. 4a shows 6 hourly upper wind data at Ponape $\left(158^{\circ} \mathrm{E}\right)$ from 15 to 25 April 1958. We recognize that southerly and northerly wind components appear alternatively at around $20 \mathrm{~km}$ height. The wind shift first occurs at around $23 \mathrm{~km}$ height and progresses downward. A comparison of Fig. 4a with Fig. 4b which shows similar analysis at Canton Island $\left(172^{\circ} \mathrm{W}\right)$ further suggests that the wind shift is a reflection of moving wave-like disturbances. There is a remarkable similarity between the two time sections. The wind shift observed at Ponape at a given level laggs behind that observed at Canton Island by approximately 2 days. It is clear that large-scale wave disturbances whose phase-lines slope westward are moving against the general westerly flow.

In. Fig. 5, streamline analysis of $70,000 \mathrm{ft}$ winds over the equatorial Pacific area during this period is illustrated. A large-scale retrogressive wave is clearly recog nized. 

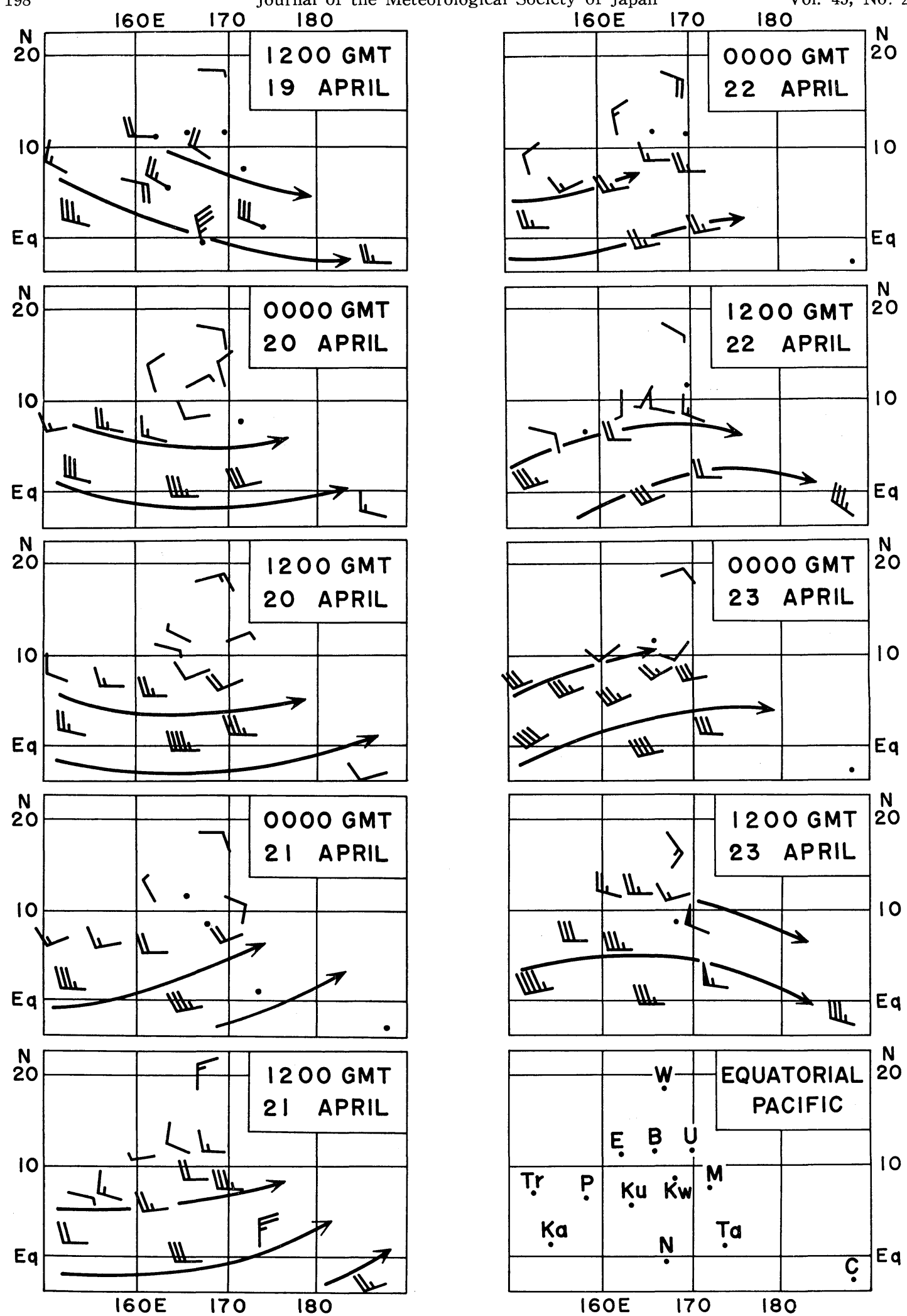

Fig. 5. 70,000-ft streamline charts over the equatorial Pacific area for 19-23 April 1958, Observation stations are shown in the right bottom, 


\section{Remarks}

Extensive survey of disturbances in the equatorial stratosphere around the globe for longer records has not yet been taken up. However, casual inspection of the I.G.Y. data suggests the existence of similar waves in other areas. An example observed over the central Africa is shown in Fig. 6.
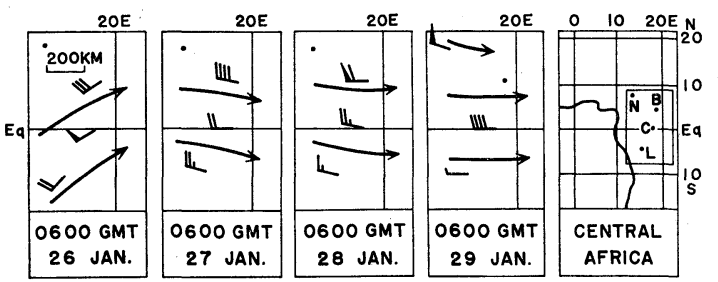

Fig. 6. $20 \mathrm{~km}$ streamline charts over the central Africa for 26-29 January 1958. Stations are Ngaoundéré (N), Bangui (B), Conquilhatville (C) and Léopoldville (L).

The origin, the dynamics and the significance in the maintenance of mean zonal wind of the wave disturbance cannot be clarified until we further reveal quantitative aspects of the disturbance. Determination of the amplitude and the average period of disturbance based on the Pacific data of 1958 is in progress and will be reported elsewhere.

\section{Acknowledgments}

The authors express their appreciation to Prof. S. Syōno and other members of the Geophysical Institute for their interest in this study. Mr. S. Nakamura of the Japan Meteorological Agency has kindly supplied the I.G.Y. data over Africa. Thanks are extended to Mrs. I. Akamatsu and Miss M. Onozuka for their assistance.

This research has been partially supported through a grant from the Japan Society for the Promotion of Science as part of the JapanU.S. Cooperative Science Program.

\section{Reference}

Yanai, M. and T. Maruyama, 1966 : Stratospheric wave disturbances propagating over the equatorial Pacific. J. meteor. Soc. Japan, 44, 291294.

\section{Data}

A. Joint Task Force Seven Meteorological Center, 1958: Meteorological Report on Operation Hardtack, 1958. JTFMC TP-8, Vols. 1-6.

B. U.S. Weather Bureau: Daily Series, Synoptic Weather Maps, Part II, Northern Hemispheric Data Tabulations.

C. World Meteorological Organization: I. G. Y. Upper Wind Data (microcards).

\title{
赤道地方下部成層圈における大規模波動擾乱の存在
}

\author{
丸山健人・柳井迪雄
}

